\title{
Constructivist Approach: Students’ Attitude towards the Physics Learning in Vocational High Schools
}

\author{
Tuwoso, Widiyanti, Andika Bagus Nur Rahma Putra \\ Mechanical Engineering Department, EngineeringFaculty \\ Universitas Negeri Malang \\ Malang, Indonesia \\ tuwoso.ft@um.ac.id
}

\begin{abstract}
The principles of constructivism have been widely used in science education. Constructivism emphasises knowledge as students' active construction. A teacher acts as a mediator, convinces what students know, and organises tasks so that students can build knowledge. Students work out meaning in a small group, and then seek approval in a large group/the whole class. The teacher's duties are to monitor student understanding and guide the discussion so that each student actively participates and gets the opportunity to express ideas. This research used descriptive quantitative method. This method was chosen to describe students' attitude towards physics lessons using the constructivist approach. The research participants were 136 tenth grade students from 4 different schools. The subjects of this study were students who learned physics with the use of constructivist approach. The data gathered were analysed descriptively. The results showed that $69.90 \%$ students expressed a very positive attitude towards the physics lessons using the constructivist approach and the rest $(30.10 \%)$ expressed a positive attitude. Regarding students' attitude towards their physics teacher using the constructivist approach, most students $(\mathbf{7 0 . 5 0 \% )}$ expressed a very positive attitude and $29.50 \%$ students displayed a positive attitude.
\end{abstract}

Keywords—constructivist approach, physics learning

\section{INTRODUCTION}

Behaviourists regard psychology as a study of behaviour and view students as a behavioural response to physical stimulation. Educators who apply the behaviourist frameworks usually plan the curriculum by organising the content knowledge into small parts indicated by a certain skill. Then, these parts are arranged hierarchically, from simple to complex. Behaviourists assume that if students listen well to a teacher's explanation or engage in an experience, the learning activity will be effective. According to Fosnot [1], students are considered passive, need external motivation, and influenced by reinforcement. Therefore, educators should develop a well-structured curriculum and determine how students should be motivated, stimulated, and evaluated. Student progress is measured by observable results. Constructivism is different from behaviourism; constructivism emphasises knowledge as students' active construction [1]. According to constructivism, if one does not construct his own knowledge actively, even into old age, his knowledge cannot develop.

The principles of constructivism have been widely used in science and mathematics education. The principles often derived from constructivism include: (1) knowledge is actively constructed by students; (2) pressure in the learning process lies in the students; (3) teaching is to help students learn, (4) learning process emphasises more on process, not outcome; (5) curriculum emphasises student participation; and (6) teachers act as facilitators [2]. These principles are widely adopted to create an effective lesson plan, prepare for a curriculum renewal, plan a teacher preparation programme, and evaluate existing teaching and learning practice.

Wheatley devised a curriculum applying a problemcentred approach in which students work together in groups, interpret the issues given, and try to solve complex problems. The teacher acts as a mediator, convinces what students know, and organises tasks so that students can build knowledge. Students work out meaning in a small group, and then seek approval in a large group/the whole class. The teacher's duties are to monitor student understanding and guide the discussion so that each student actively participates and gets the opportunity to express ideas. The teacher also involves in the instructional activities, such as asking for justification, checking facts, and evaluating alternatives. In fact, a teacher can serve as a mediator, guide, and learning partner [3].

As a mediator as well as facilitator, a teacher has these following tasks: (1) providing learning experiences that enable students to be responsible for planning, processing, and conducting research [2]; (2) opening up opportunities that support student learning; and (3) monitoring and assessing students' reasoning and thought processes. In order to accomplish tasks and responsibilities, a teacher should: (1) interact well with students to better understand what they know and think about; (2) understand which learning experience best suits students' needs; and (3) have flexible thinking to be able to understand and appreciate students' opinions [2].

On the basis of the above description, this paper seeks to address: (1) students' attitudes towards the instructional process, and (2) students' attitudes towards the teacher. The assessment of students' attitudes towards the physics lessons included: the arrangement of the learning environment, the use of instructional strategies, the attraction of the lesson, and the convenience of learning. The students' attitudes toward teachers included: the role of the teacher as a facilitator, the learning orientation provided by the teacher, the choices of learning strategies, the learning resources and the time given by the teacher. 


\section{METHOD}

\section{A. Research Model}

This research used the descriptive quantitative method. This method was chosen to describe students' attitude towards physics lessons using the constructivist approach. The attitudes assessed included students' attitudes towards the instructional process and teacher.

\section{B. Maintaining the Integrity of the Specifications}

The research participants were 136 tenth grade students from 4 different schools. The research took place in four vocational high schools located in Malang, namely: (1) SMK Singosari and SMK Kepanjen (Malang district), and (2) SMK Madyopuro and SMK Bakalan (Malang city). The subjects of this study were students learning physics learning with the use of the constructivist approach.

\section{Data Collection}

The instruments for this research included a questionnaire. The questionnaires were utilized to collect data. The questionnaire was also used to collect data on the validity and reliability.

\section{Data Analysis}

The data gathered were analysed descriptively. The data were analysed by calculating the average score using four categories, i.e., Strongly Agree, Agree, Undecided, Disagree, and Strongly Disagree.

\section{RESUlT AND DISCUSSION}

\section{A. Attitudes of Students at SMK Madyopuro towards Instructional Process and Teacher}

There are $61.11 \%$ of students expressed a very positive attitude towards the use of the constructivist approach to learning physics, and the rest $(38.89 \%)$ displayed just a positive attitude. Regarding students' attitudes towards their physics teacher, $44.44 \%$ students displayed a very positive and $55.56 \%$ students displayed a positive attitude. The frequency distribution of scores representing students' attitudes towards the learning process and teacher using the constructivist approach is presented in Table I.

TABLE I. THE FREQUENCY DISTRIBUTION OF SCORES REPRESENTING THE ATTITUDE OF STUDENTS AT SMK MADYOPURO TOWARDS THE LEARNING PROCESS AND TEACHER

\begin{tabular}{|l|c|c|c|c|c|c|}
\hline \multirow{2}{*}{ Description } & \multicolumn{6}{|c|}{ Students' attitude towards } \\
\cline { 2 - 7 } & \multicolumn{2}{|c|}{ Instructional process } & \multicolumn{3}{c|}{ Physics teacher } \\
\cline { 2 - 7 } & Score & $\boldsymbol{f}$ & $\boldsymbol{\%}$ & Score & $\boldsymbol{f}$ & $\%$ \\
\hline $\begin{array}{l}\text { Strongly } \\
\text { Agree }\end{array}$ & 5 & 22 & 61,11 & 5 & 16 & 44,44 \\
\hline Agree & 4 & 14 & 38,89 & 4 & 20 & 55,56 \\
\hline Undecided & 3 & 0 & 0 & 3 & 0 & 0 \\
\hline Disagree & 2 & 0 & 0 & 2 & 0 & 0 \\
\hline $\begin{array}{l}\text { Strongly } \\
\text { Disagree }\end{array}$ & 1 & 0 & 0 & 1 & 0 & 0 \\
\hline $\mathrm{N}$ & & 36 & 100 & & 36 & 100 \\
\hline
\end{tabular}

\section{B. Attitude of Students at SMK Bakalan towards} Instructional Process and Teacher

Most students $(82.35 \%)$ expressed a very positive attitude towards the use of the constructivist approach to learning physics, and the rest (17.65\%) displayed a positive attitude. Moreover, $79.41 \%$ students displayed a very positive and $20.59 \%$ students displayed a positive attitude towards their physics teacher. The frequency distribution of scores representing students' attitudes towards the learning process and teacher using the constructivist approach can be found in Table II.

TABLE II. THE FREQUENCY DISTRIBUTION OF SCORES REPRESENTING THE ATTITUDE OF STUDENTS AT SMK BAKALAN TOWARDS THE LEARNING PROCESS AND TEACHER

\begin{tabular}{|l|l|l|l|l|l|l|}
\hline \multirow{3}{*}{ Description } & \multicolumn{6}{|c|}{ Students' attitude towards } \\
\cline { 2 - 7 } & \multicolumn{2}{|c|}{ Instructional process } & \multicolumn{3}{c|}{ Physics teacher } \\
\cline { 2 - 8 } & Score & $\boldsymbol{f}$ & $\boldsymbol{\%}$ & Score & $\boldsymbol{f}$ & $\%$ \\
\hline Strongly Agree & 5 & 28 & 82.35 & 5 & 27 & 79.41 \\
\hline Agree & 4 & 6 & 17.65 & 4 & 7 & 20.59 \\
\hline Undecided & 3 & 0 & 0 & 3 & 0 & 0 \\
\hline Disagree & 2 & 0 & 0 & 2 & 0 & 0 \\
\hline Strongly Disagree & 1 & 0 & 0 & 1 & 0 & 0 \\
\hline N & & 34 & 100 & & 34 & 100 \\
\hline
\end{tabular}

\section{Attitudes of Students at SMK Singosari towards} Instructional Process and Teacher

Regarding students' attitudes towards the instructional process, most students $(78.12 \%)$ expressed a very positive attitude and $21.88 \%$ students displayed a positive attitude. Most students $(87.50 \%)$ also displayed a very positive attitude towards their physics teacher; the rest $(12.50 \%)$ a displayed a positive attitude. The frequency distribution of scores representing students' attitudes towards the learning process and teacher using the constructivist approach is presented in Table III.

TABLE III. THE FREQUENCY DISTRIBUTION OF SCORES REPRESENTING THE ATTITUDE OF STUDENTS AT SMK SINGOSARI TOWARDS THE LEARNING PROCESS AND TEACHER

\begin{tabular}{|l|c|c|c|c|c|c|}
\hline \multirow{3}{*}{ Description } & \multicolumn{6}{|c|}{ Students' attitude towards } \\
\cline { 2 - 7 } & \multicolumn{2}{|c|}{ Instructional process } & \multicolumn{3}{c|}{ Physics teacher } \\
\cline { 2 - 7 } & Score & $\boldsymbol{f}$ & $\%$ & Score & $\boldsymbol{f}$ & $\%$ \\
\hline Strongly Agree & 5 & 25 & 78,12 & 5 & 28 & 87,50 \\
\hline Agree & 4 & 7 & 21,88 & 4 & 4 & 12,50 \\
\hline Undecided & 3 & 0 & 0 & 3 & 0 & 0 \\
\hline Disagree & 2 & 0 & 0 & 2 & 0 & 0 \\
\hline Strongly Disagree & 1 & 0 & 0 & 1 & 0 & 0 \\
\hline N & & 32 & 100 & & 32 & 100 \\
\hline
\end{tabular}

\section{Attitudes of Students at SMK Kepanjen towards Instructional Process and Teacher}

Half of the students expressed a very positive attitude, and the other half expressed a positive attitude towards the use of the constructivist approach to learning physics. In terms of students' attitude towards their physics teacher, $70.59 \%$ students displayed a very positive and $29.41 \%$ of them displayed a positive attitude. The frequency distribution of scores representing students' attitudes towards the learning process and teacher using the constructivist approach can be found in Table IV. 
TABLE IV.THE FREQUENCY DISTRIBUTION OF SCORES REPRESENTING THE ATTITUDE OF STUDENTS AT SMK KEPANJEN TOWARDS THE LEARNING PROCESS AND TEACHER

\begin{tabular}{|l|c|c|c|c|c|c|}
\hline \multirow{3}{*}{ Description } & \multicolumn{6}{|c|}{ Students' attitude towards } \\
\cline { 2 - 7 } & \multicolumn{2}{|c|}{ Instructional process } & \multicolumn{3}{c|}{ Physics teacher } \\
\cline { 2 - 7 } & Score & $f$ & $\%$ & Score & $f$ & $\%$ \\
\hline Strongly Agree & 5 & 17 & 50 & 5 & 24 & 70,59 \\
\hline Agree & 4 & 17 & 50 & 4 & 10 & 29,41 \\
\hline Undecided & 3 & 0 & 0 & 3 & 0 & 0 \\
\hline Disagree & 2 & 0 & 0 & 2 & 0 & 0 \\
\hline Strongly Disagree & 1 & 0 & 0 & 1 & 0 & 0 \\
\hline N & & 34 & 100 & & 34 & 100 \\
\hline
\end{tabular}

The results showed that $69.90 \%$ students expressed a very positive attitude towards the teaching-learning process of physics using the constructivist approach. Most students responded very positively because they were happy to be taught using the applied learning approach; they could build their own knowledge, both individually and socially, they said. Since the knowledge was constructed individually and collectively, collaborative learning groups could be developed. In the constructivist approach, students are viewed as subjects of the instructional process.

It is clear that in constructivism, learning is an active activity in which students build their own knowledge. Students construct meaning from what they learn. It is a process of adapting new concepts and ideas to the existing frame of mind of students [4]. Von Glasersfeld [5] explained how constructivism affects learning in groups. According to Von Von Glasersfeld, in a study group, students should explain how they see a problem and how they deal with it. Students' effort to explain something to their friends actually helps them to see things more clearly and even to recognise their own inconsistencies. Betterncourt [6] pointed out that students should actively build their own knowledge in the learning process. It is the process of adapting new concepts and ideas to students' existing frame of mind.

Regarding students' attitude towards their physics teacher using the constructivist approach, most students (70.50\%) expressed a very positive attitude. According to constructivism, a teacher is not someone who knows everything and students are not the uninitiated. In the instructional process, students actively construct knowledge, and the teacher helps them to work more optimally. In other words, teachers and students work together to build knowledge. In this case, the teacher plays a role as a learning partner.

The constructivist view emphasises the development of the learning environment. In order to achieve that, the learning strategy should consist of the following principles: a teacher should (1) present a problem in a context appropriate to the level of student development; (2) structure the learning around the primary concepts; (3) encourage students to ask their own questions; (4) motivate students to find answers to their own questions; (5) stimulate students to express their opinions and appreciate their point of view; (6) challenge students to gain a deep understanding, not just to accomplish tasks; (7) encourage students to work in collaboration, (8) encourage students to accept responsibility; and (9) assess the learning process and student achievement [7]. Also, a teacher should involve students in activities that arouse their curiosity and stimulate them to speak up or communicate their scientific ideas [8].

\section{CONCLUSION}

The results showed that $69.90 \%$ students expressed a very positive attitude towards the physics lessons using the constructivist approach and the rest $(30.10 \%)$ expressed a positive attitude. Regarding students' attitude towards their physics teacher using the constructivist approach, most students $(70.50 \%)$ expressed a very positive attitude and $29.50 \%$ students displayed a positive attitude. On the basis of the results above, it can be concluded that the role of a teacher as a facilitator and mediator is essential in the instructional process using the constructivist approach. Constructivism requires teachers to be deep and broadminded, patient, and also open to different ideas. Teachers should be given the freedom to select and develop any kinds of appropriate facilities and resources to enhance student creativity in constructing their knowledge.

\section{REFERENCES}

[1] C.T. Fosnot, Constructivism: Theory, perspectives and practice. 2nd edition. (New York: Teachers College Press, 2005).

[2] P.Suparno, Education Constructivists Philosophy (Ind: Filsafat konstruktivisme dalam pendidikan). Yogyakarta: Kanisius. 1988).

[3] K. Tobin, D..Tippins, , \& A. Gallard, In D. Gobel (Eds.), Handbook of Research on Science Teaching and Learning. New. York: Macmillan Publishing Company.1994.

[4] J. Shymansky, Using Constructivist Ideas to Teach Science Teachers about Constructivist Ideas, or Teachers are students Too. Journal of Science Teacher Education, 3, 2, 53-57,1992

[5] E. Von Glasersfeld. Knowing without Metaphysics: Aspects of the Rdical Constructivist Position. In F. Steier (Ed). Research and Reflexivity: Toward a Cybernetic/Social Constructivist Way of Knowing: London: Sage. 1989

[6] Tuwoso, "The Development of Physic Learning Models with Constructivism Approach in Vocational High School" (Ind: Pengembangan Model Pembelajaran Fisika di SMK dengan Pendekatan Konstruktivistik). Dissertation. Yogyakarta: Program Pascasarjana Universitas Negeri Yogyakarta.2011

[7] A. Bettencourt. What is constructivism and why are they all talking about it?. (Michigan State University. 1989)

[8] M. Watts. \& M. Pope "Thinking about Thinking, Learning about Learning: Constructivism in Physics Education. Physics Education, 24:326. (1989) 